Article

\title{
Covellite (CuS) Production from a Real Acid Mine Drainage Treated with Biogenic $\mathrm{H}_{2} \mathrm{~S}$
}

\author{
Patricia Magalhães Pereira Silva ${ }^{1}$, Adriano Reis Lucheta ${ }^{1}$ (), José Augusto Pires Bitencourt ${ }^{2}$, \\ Andre Luiz Vilaça do Carmo ${ }^{1}$, Ivan Patricio Nancucheo Cuevas ${ }^{3}$, José Oswaldo Siqueira ${ }^{2}$, \\ Guilherme Corrêa de Oliveira ${ }^{2, *}$ and Joner Oliveira Alves $1, *$ (i) \\ 1 SENAI Innovation Institute for Mineral Technologies, National Service for Industrial Training (SENAI), \\ Belém/PA 66035-405, Brazil; patricia.isi@senaipa.org.br (P.M.P.S.); adriano.isi@senaipa.org.br (A.R.L.); \\ andreluiz.isi@senaipa.org.br (A.L.V.d.C.) \\ 2 Instituto Tecnológico Vale, Belém/PA 66055-090, Brazil; jose.augusto.bitencourt@itv.org (J.A.P.B.); \\ jose.oswaldo.siqueira@itv.org (J.O.S.) \\ 3 Facultad de Ingeniería y Tecnología, Universidad San Sebastián, Concepción 4080871, Chile; \\ ivan.nancucheo@uss.cl \\ * Correspondence: guilherme.oliveira@itv.org (G.C.d.O.); joner@pq.cnpq.br (J.O.A.)
}

Received: 6 December 2018; Accepted: 1 February 2019; Published: 9 February 2019

\begin{abstract}
Acid Mine Drainage (AMD) is an environmental problem associated with mining activities, which resulted from the exposure of sulfur bearing materials to oxygen and water. AMD is a pollution source due to its extreme acidity, high concentration of sulfate, and soluble metals. Biological AMD treatment is one alternative to couple environmental amelioration for valuable dissolved metals recovery, as a new source of raw materials. Covellite $(\mathrm{CuS})$ particles were synthetized from an AMD sample collected in a Brazilian copper mine, after 48 and $96 \mathrm{~h}$ of exposure to hydrogen sulfide $\left(\mathrm{H}_{2} \mathrm{~S}\right)$ produced in a bioreactor containing acidophilic sulfate reducing bacteria (SRB). The time of exposure affected the morphology, nucleation, and size of CuS crystals. CuS crystals synthetized after $96 \mathrm{~h}$ of $\mathrm{H}_{2} \mathrm{~S}$ exposure showed better ordination as indicated by sharp and intense diffractograms obtained by X-ray diffraction (XRD), and the predominance of placoid sheets with hexagonal habit structure as observed by scanning electrons microscopy (SEM). Energy dispersive X-ray fluorescence (EDXRF) spectrometry indicated a Cu:S molar ratio in agreement with CuS. Granulometric analysis demonstrated that $90 \%$ of CuS particles were less than $22 \mu \mathrm{m}$ size. AMD biological treatment is a potential economical CuS recovery option for metallurgical process chain incorporation, or new industrial applications, since the alteration of synthesis conditions can produce different crystal forms with specific characteristics.
\end{abstract}

Keywords: biomining; biosulfidogenesis; acid mine drainage; copper; waste management

\section{Introduction}

Acid mine drainage (AMD) is an acidic and metal-rich effluent that occurs as a result of mineral sulfides (e.g., pyrite) exposure to water, oxygen, and iron/sulfur oxidizing bacteria, such as Acidithiobacillus ferrooxidans and A. thiooxidans, among others. AMD can reach extremely low $\mathrm{pH}(<2)$, show high sulfate ( $>20.000 \mathrm{~g} / \mathrm{L})$ and soluble metals/metalloids concentrations [1], thus comprising an environmental thread and a pollution source for groundwater, rivers, and soils [2].

Chemical AMD remediation by the addition of alkaline substances is the most common approach adopted for $\mathrm{pH}$ neutralization and metals/metalloids precipitation. However, new biological strategies using acidophilic sulfate reducing bacteria (SRB) are gaining force due to the possibility of valuable metal recovery [3]. Despite its simplicity, limestone $\left(\mathrm{CaCO}_{3}\right)$ application generates high amounts of 
toxic slurry composed by metal hydroxides and carbonate precipitates that must be safely removed and stored to avoid environmental contamination, thereby raising treatment costs [4]. The main advantage of AMD bioremediation by SRB is the absence of sludge generation-excluding transport and storage costs-in addition to the selective soluble valuable metals recovery that can alleviate treatment costs.

Under anaerobic conditions, SRB reduces the sulfate $\left(\mathrm{SO}_{4}{ }^{2-}\right)$ in AMD to hydrogen sulfide $\left(\mathrm{H}_{2} \mathrm{~S}\right)_{(\mathrm{g})}$, using organic carbon sources (e.g., carbohydrates $\left(\mathrm{CH}_{2} \mathrm{O}\right)$, ethanol $\left(\mathrm{C}_{2} \mathrm{H}_{5} \mathrm{OH}\right)$, and glycerol $\left(\mathrm{C}_{3} \mathrm{H}_{8} \mathrm{O}_{3}\right)$; Equation (1)) or inorganic (e.g., $\left.\mathrm{H}_{2}\right)$ substrates as electron donors. This process neutralizes the $\mathrm{pH}$ because the reaction is proton consuming [5]. Soluble metals $(\mathrm{Me})$ such as $\mathrm{Cu}^{2+}, \mathrm{Zn}^{2+}$, and $\mathrm{Cd}^{2+}$, chemically react with $\mathrm{H}_{2} \mathrm{~S}_{(\mathrm{g})}$, precipitating in the form of insoluble metallic sulfides $(\mathrm{MeS})$, see Equation (2).

$$
\begin{gathered}
2 \mathrm{CH}_{2} \mathrm{O}+\mathrm{SO}_{4}^{2-}+2 \mathrm{H}^{+} \rightarrow \mathrm{H}_{2} \mathrm{~S}+2 \mathrm{H}_{2} \mathrm{CO}_{3} \\
\mathrm{H}_{2} \mathrm{~S}+\mathrm{Me}^{2+} \rightarrow \mathrm{MeS}_{(s)}+2 \mathrm{H}^{+} \\
\mathrm{Me}=\mathrm{Cu}^{2+}, \mathrm{Zn}^{2+}, \mathrm{Ni}^{2+}, \mathrm{Pb}^{2+}, \mathrm{Cd}^{2+}, \mathrm{Co}^{2+}
\end{gathered}
$$

Mining waste (e.g., tailings and AMD) reused as raw materials are an opportunity for mitigating environmental impacts of the mining sector, and contribute to a circular economy. Biological AMD treatment by SRB is an example of an environmentally friendly technology to both ameliorate the effluent quality and open the possibility for the development of new products with aggregated value. Previous studies applying the biological AMD treatment by SRB, showed the potential for metal sulfide nanoparticle synthesis [6], which can be used as adsorbents, due to their small size, high reactivity, and large surface energy; with quick sorption capacity [7], solar cells components due to its optical activities [8], and fungicide beyond other industrial applications [9].

In Brazil, due to the specific geological origin [10,11], around $40 \%$ of the Amazon region territory is associated to metal deposits that comprise a hotspot for mineral exploration. In 2016, Pará State-the eastern border of Amazon Rainforest-alone processed 87\% of all copper ore (89 million tons) extracted in the country [12], raising extra concerns about the environmental impacts of mining activities. Environmental conservation of the Amazon region requires the development of new technologies that allow mine exploration for as long as possible, avoiding new pits opening as well as mining wastes safety management and reuse generating value.

The aim of this work was to optimize the synthesis of covellite crystals by exposing real AMD, collected from a copper mine in the Amazon region, to $\mathrm{H}_{2} \mathrm{~S}$ produced by a sulfidogenic bioreactor.

\section{Materials and Methods}

\subsection{Sulfidogenic Bioreactor Assemble}

An up-flow sulfidogenic stirred tank reactor (Fermac 2000, Electrolab Biotech, Tewkesbury, UK), with a working volume of $2.3 \mathrm{~L}$, was inoculated with an acidophilic SRB consortium, obtained from an anaerobic sediment found in an acidic river located in northern Chile, and operated under continuous flow, according to Nancucheo and Johnson [13]. The bacterial consortium was immobilized on a 1-2 mm diameter porous glass beads, occupying $40 \%$ of the vessel's volume, and the anoxic condition was maintained through $150 \mathrm{~mL} / \mathrm{min} \mathrm{N}_{2} / \mathrm{CO}_{2(\mathrm{~g})}(70 / 30 \%)$ injection. The $\mathrm{pH}(4.5)$, temperature $\left(30^{\circ} \mathrm{C}\right)$, and agitation $(40 \mathrm{rpm})$ were constantly monitored using an automatic control unit coupled to the bioreactor (Tec-Bio-Flex, Tecnal, Piracicaba, Brazil).

The bioreactor was fed with a sterile synthetic AMD $(\mathrm{pH}=2.5)$, reproducing the chemical composition of real AMD found in Brazilian copper mines (Table 1), with the exception of Cu [14], supplied with $5 \mathrm{mM}$ of glycerol (electron donor) and $0.01 \%(\mathrm{w} / \mathrm{v})$ of yeast extract (peptides and B vitamin source). Synthetic AMD without $\mathrm{Cu}$ was automatically injected by a coupled $\mathrm{pH}$ controlling peristaltic pump in response to $\mathrm{pH}$ increase, since sulfate reduction is a proton consuming reaction [14]. 
Table 1. Chemical composition of the synthetic Acid Mine Drainage (AMD) feed in the bioreactor.

\begin{tabular}{cc}
\hline Ion Solution & Concentration $(\mathrm{mM})$ \\
\hline $\mathrm{Ca}^{2+}$ & 7.00 \\
$\mathrm{Mg}^{2+}$ & 4.00 \\
$\mathrm{Na}^{+}$ & 2.10 \\
$\mathrm{~K}^{+}$ & 0.28 \\
$\mathrm{Ni}^{2+}$ & 0.27 \\
$\mathrm{Mn}^{2+}$ & 0.15 \\
$\mathrm{Co}^{2+}$ & 0.04 \\
$\mathrm{Zn}^{2+}$ & 0.02 \\
$\mathrm{SO}_{4}{ }^{2-}$ & 13.86 \\
$\mathrm{Cl}^{-}$ & 0.04 \\
\hline
\end{tabular}

\subsection{Covellite Synthesis}

The mineral sulfide was precipitated off-line by sparging the $\mathrm{H}_{2} \mathrm{~S}$ generated in the sulfidogenic bioreactor (carried by the $\mathrm{N}_{2} / \mathrm{CO}_{2}$ injection), during $48 \mathrm{~h}$ (CuS48) or $96 \mathrm{~h}$ (CuS96), in a Schott glass bottle (Sigma-Aldrich, Saint Louis, MI, USA) equipped with a screw cap with two stainless steel ports, containing $1 \mathrm{~L}$ of a real AMD sample collected in a copper mine located at Pará State, in Brazil (Figure 1). The AMD sample was characterized by a moderate acidic $\mathrm{pH}(\mathrm{pH}=5.1)$ (Orion Star A211 pHmeter, Thermo Fischer, Waltham, MA, USA), high conductivity $(2590 \mu \mathrm{S} / \mathrm{cm}$, SMWW 2510-B method) and soluble metal presence $\left(\mathrm{Zn}=0.12 \mathrm{mg} \cdot \mathrm{L}^{-1}, \mathrm{Mn}=10.50 \mathrm{mg} \cdot \mathrm{L}^{-1}\right.$, and $\mathrm{Cu}=325 \mathrm{mg} \cdot \mathrm{L}^{-1}$, EPA 3010 A: 1992 method). The dark precipitate was collected by vacuum filtration using a vacuum pump (mod.131, Prismatec, Itu, Brazil) in quantitative filter paper, and oven-dried at $60^{\circ} \mathrm{C}$ overnight, before characterization (Figure 1).

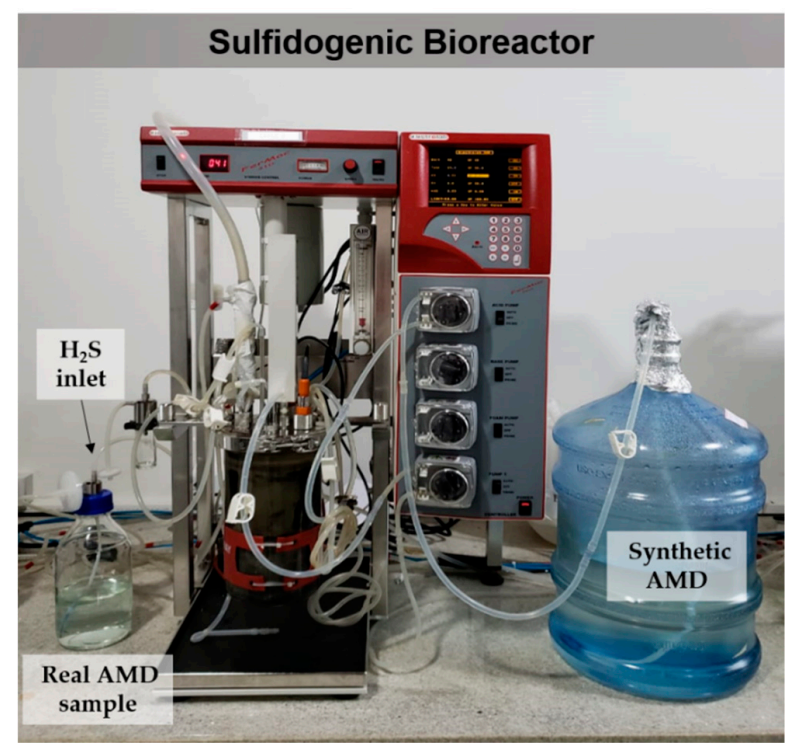

Figure 1. Real AMD sample (Schott glass bottle) exposed to biogenic $\mathrm{H}_{2} \mathrm{~S}$ for covellite (CuS) production.

\subsection{Characterization}

The chemical composition of dried precipitate was determined by Energy Dispersive X-ray Fluorescence (EDXRF) spectrometry (Epsilon $3^{\text {XEE }}$, PANalytical, Almelo, The Netherlands) using an $\mathrm{X}$-ray tube with Rh anode at $1.5 \mathrm{~W}$ (PANalytical, Almelo, The Netherlands). Mineralogical composition was determined by $\mathrm{X}$-ray Diffraction (XRD) using a diffractometer (Empyrean, PANalytical, Almelo, The Netherlands), operating at $4^{\circ}$ to $75^{\circ} 2 \theta, 40 \mathrm{kV}, 40 \mathrm{~mA}, \mathrm{~K}_{\alpha} 1.54 \AA$, step size $0.02^{\circ}$, and a time per step of $55 \mathrm{~s}$. Diffractograms analysis and crystalline phase identification were done using the software $X^{\prime}$ pert 
HighScore Plus v.4.x LTU (Malvern-PANalytical, Malvern, UK). Morphological characterization was performed by Scanning Electron Microscopy (SEM), using a Vega 3 LMU (Tescan, Kohoutovice, Czech Republic) equipment, operated at $20 \mathrm{kV}, 10 \mu \mathrm{A}$, with focal distance between 10-15mm. Mineral samples were metallized with a thin gold layer using a Desk V metallizer (Denton Vacuum, Moorestown, NJ, USA) at $35 \mathrm{~mA}$ for $60 \mathrm{~s}$, before SEM. Granulometric analyses were conducted using a mixture of water and the powdered sample, homogenized by an ultrasonic probe (70\%) in a Mastersize 3000 (Malvern-PANalytical, Malvern, UK) equipment.

\section{Results and Discussion}

\subsection{Covellite Qualitative Analysis}

Figure 2 shows the transitional stages during the precipitation of soluble copper present in the AMD into insoluble covellite, along with the biogenic $\mathrm{H}_{2} \mathrm{~S}$ exposure time. Change in the solution's color from blue (soluble copper prevalence) to brown may be a qualitative indicator of metal sulfide nucleation and precipitation process efficiency; as a result of intermediate bisulfide, sulfide, and polysulfide formation, until the final reduction to CuS (Figure 2a,b) [15]. The obtained mineral precipitates CuS48 and CuS98 exhibited a dark blue metallic color, typical of covellite, clearing the solution after its settling (Figure 2c,d).

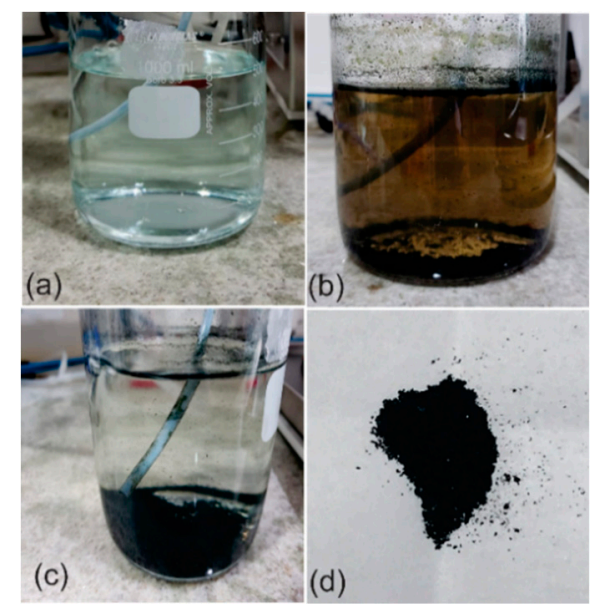

Figure 2. Transitional copper stages during Acid Mine Drainage (AMD) sample exposure to biogenic $\mathrm{H}_{2} \mathrm{~S}$. (a) AMD sample predominating the soluble copper form before biogenic $\mathrm{H}_{2} \mathrm{~S}$ exposure. (b) Initial soluble copper reduction to polysulfides by biogenic $\mathrm{H}_{2} \mathrm{~S}$. (c) Secondary polysulfides reduction to covellite by biogenic $\mathrm{H}_{2} \mathrm{~S}$. (d) Vacuum filtered and recovered dried covellite from AMD.

Metal sulfide precipitation efficiency can also be indirectly monitored by the solution's $\mathrm{pH}$ acidification in response to $\mathrm{H}^{+}$ions released during the process (Equation (2)). The final AMD sample's $\mathrm{pH}$ was 2.1, after 48 and $96 \mathrm{~h}$ exposure to biogenic $\mathrm{H}_{2} \mathrm{~S}$, favoring covellite (CuS) precipitation [16].

\subsection{Physical and Chemical Characterization}

In both samples, all observed diffractogram peaks, corresponded to the typical covellite planes (CuS) - (101), (102), (103) (006), (110), (108), and (203) - in agreement with the International Centre for Diffraction Data (ICDD) database [01-075-2233] and [03-075-2233], with the exception of plane (002) that was only observed in the CuS96 sample, but also matched the covellite profile (Figure 3). CuS96 sample' diffractogram exhibited sharper and more intense peaks compared to CuS48, indicating that the AMD time of exposure to biogenic $\mathrm{H}_{2} \mathrm{~S}$ positively influenced covellite crystals ordination. This was corroborated with the intensities of (110) and (002) diffraction planes, which indicate the presence of preferential orientation and crystal growth orientation along the c-axis [17]. 


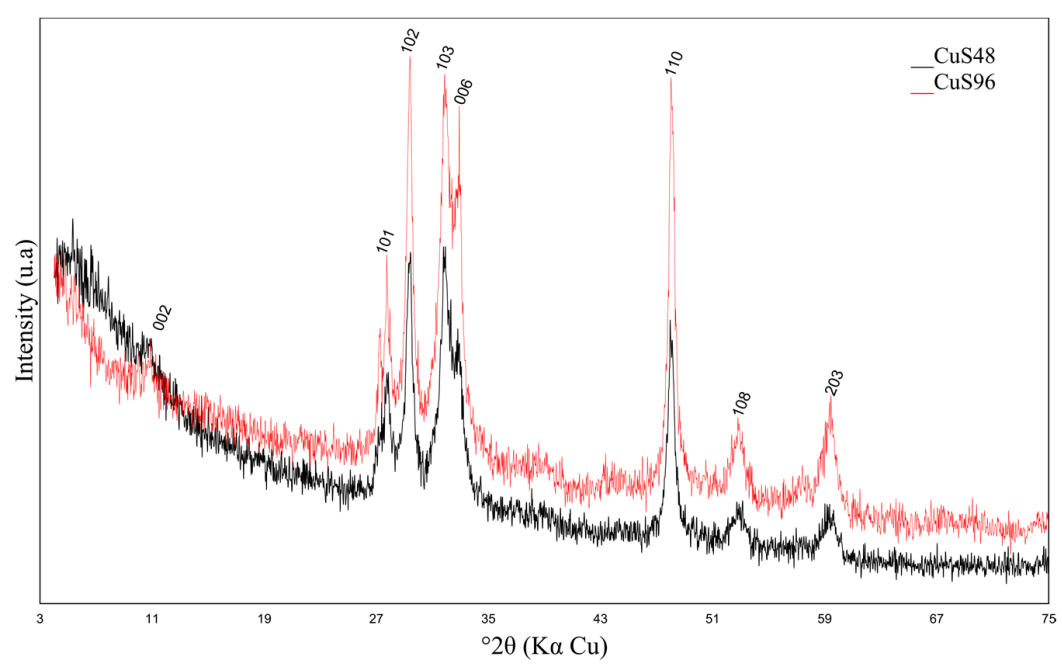

Figure 3. X-ray diffraction (XRD) diffractograms of the mineral precipitate obtained after $48 \mathrm{~h}$ (CuS48) and $96 \mathrm{~h}$ (CuS96) of AMD sample exposure to biogenic $\mathrm{H}_{2} \mathrm{~S}$.

Table 2 shows the registered cell parameters $\left[a=b, c(\AA)\right.$ e V $\left.\left(\AA^{3}\right)\right]$ of the evaluated samples. No significant deviations have been detected between the observed and theoretical parameters (ICDD database).

Table 2. Cell parameters of samples CuS48 and CuS96 compared to the ICDD database [01-075-2233].

\begin{tabular}{ccccc}
\hline Parameter & CuS48 & Theoretical & CuS96 & Theoretical \\
\hline $\boldsymbol{a}=\boldsymbol{b}(\AA)$ & $3.77 \pm 0.02$ & 3.76 & $3.78 \pm 0.004$ & 3.78 \\
$\boldsymbol{c}\left(\AA^{\mathbf{A}}\right)$ & $16.28 \pm 0.07$ & 16.27 & $16.37 \pm 0.02$ & 16.33 \\
$\boldsymbol{v}\left(\AA^{3}\right)$ & $199.9 \pm 1.78$ & 200.05 & $202.9 \pm 0.58$ & 202.98 \\
\hline
\end{tabular}

Furthermore, minor secondary phases such as: $\mathrm{Cu}_{2} \mathrm{~S}$ (chalcocite), $\mathrm{Cu}_{1.96} \mathrm{~S}$ (dijurliete), $\mathrm{Cu}_{1.8} \mathrm{~S}$ (digenite), $\mathrm{Cu}_{1.75} \mathrm{~S}$ (anilite), $\mathrm{Cu}_{1.12} \mathrm{~S}$ (yarrowite), and/or zinc phase $\mathrm{ZnS}$ (sphalerite) were not observed at the technique detection limits, possiblly due to excessive $\mathrm{H}_{2} \mathrm{~S}$ production by the acidophilic SRB consortia inhibiting other phases [18]. Pure covellite formation was also expected due to higher amounts of soluble copper in the AMD sample compared to other metals ( $\mathrm{Zn}$ and $\mathrm{Mn}$ ) and strong $\mathrm{H}_{2} \mathrm{~S}$ dissolution favored under $\mathrm{pH}<8.0$ [15].

Table 3 describes the chemical composition (EDXRF) of the obtained mineral sulfide samples. Both samples were predominantly composed of copper and sulfur, with minor concentrations of silicon and aluminum. The elemental Cu:S ratio of the CuS48 sample was 1.18 ( $\mathrm{wt} \% \mathrm{Cu}=87.67 ; \mathrm{wt} \%$ $\mathrm{S}=73.99)$, whereas in the CuS96 sample it was $0.67(\mathrm{wt} \% \mathrm{Cu}=70.97 ; \mathrm{wt} \% \mathrm{~S}=106.08)$, which were in agreement with the accepted synthetic covellite $\mathrm{Cu}: \mathrm{S}$ ratio $(0.5 \geq \mathrm{CuS} \leq 2)[15,19,20]$. These results confirm the predominance of covellite crystals and the absence of accessory minerals in agreement with XRD diffractograms. Since the same AMD sample was used in both assays, the observed Cu:S ratio variation was probably associated with the time of exposure to biogenic $\mathrm{H}_{2} \mathrm{~S}$ or methodological bias during sample preparation (loose powder).

Table 4 shows the particles diameter distribution $\left(\mathrm{Dv}_{(10)}, \mathrm{Dv}_{(50)}\right.$, and $\left.\mathrm{Dv}_{(90)}\right)$ of the samples. $\mathrm{Dv}$ index characterizes the particle size distributions, which are calculated through intercepts to 10,50 , and $90 \%$ of the cumulative volume [21]. In general, the higher exposure time of AMD to biogenic $\mathrm{H}_{2} \mathrm{~S}$ (CuS96) resulted in smaller covellite particles as observed by $\mathrm{Dv}_{(90)}$ and $\mathrm{Dv}_{(50)}$ distribution parameter (Figure 4). In sample CuS96, 90\% of the particles had a size of $22 \mu \mathrm{m}$ or less, whereas $90 \%$ of the particles in sample CuS48 had a size of $43.4 \mu \mathrm{m}$ or sless. The smallest obtained covellite particle sizes were below 0.37 and $0.42 \mu \mathrm{m}$ in samples CuS96 and CuS48, respectively, representing $10 \%$ of the samples size distribution $\left(\operatorname{Dv}_{(10)}\right)$. 
Table 3. Semi-quantitative chemical composition ( $w \mathrm{t} \%$ ) of the mineral sulfide samples.

\begin{tabular}{ccc}
\hline $\mathbf{w t} \%$ & CuS48 & CuS96 \\
\hline $\mathrm{Cu}$ & 87.67 & 70.97 \\
$\mathrm{~S}$ & 73.99 & 106.08 \\
$\mathrm{Si}$ & 0.09 & 0.11 \\
$\mathrm{Al}$ & 0.07 & 0.09 \\
Others $^{*}$ & - & - \\
\hline
\end{tabular}

Table 4. Particles size distribution (microns) in samples CuS48 and CuS96.

\begin{tabular}{cccccc}
\hline Samples & $\mathbf{D v}_{\mathbf{1 0}}$ & $\mathbf{D v}_{\mathbf{5 0}}$ & $\mathbf{D v}_{\mathbf{9 0}}$ & $\mathbf{D v}_{\mathbf{4 . 3}}$ & Span \\
\hline CuS48 & 0.42 & 10.5 & 43.4 & 27.2 & 4.08 \\
CuS96 & 0.37 & 3.05 & 22 & 12.3 & 7.09 \\
\hline
\end{tabular}
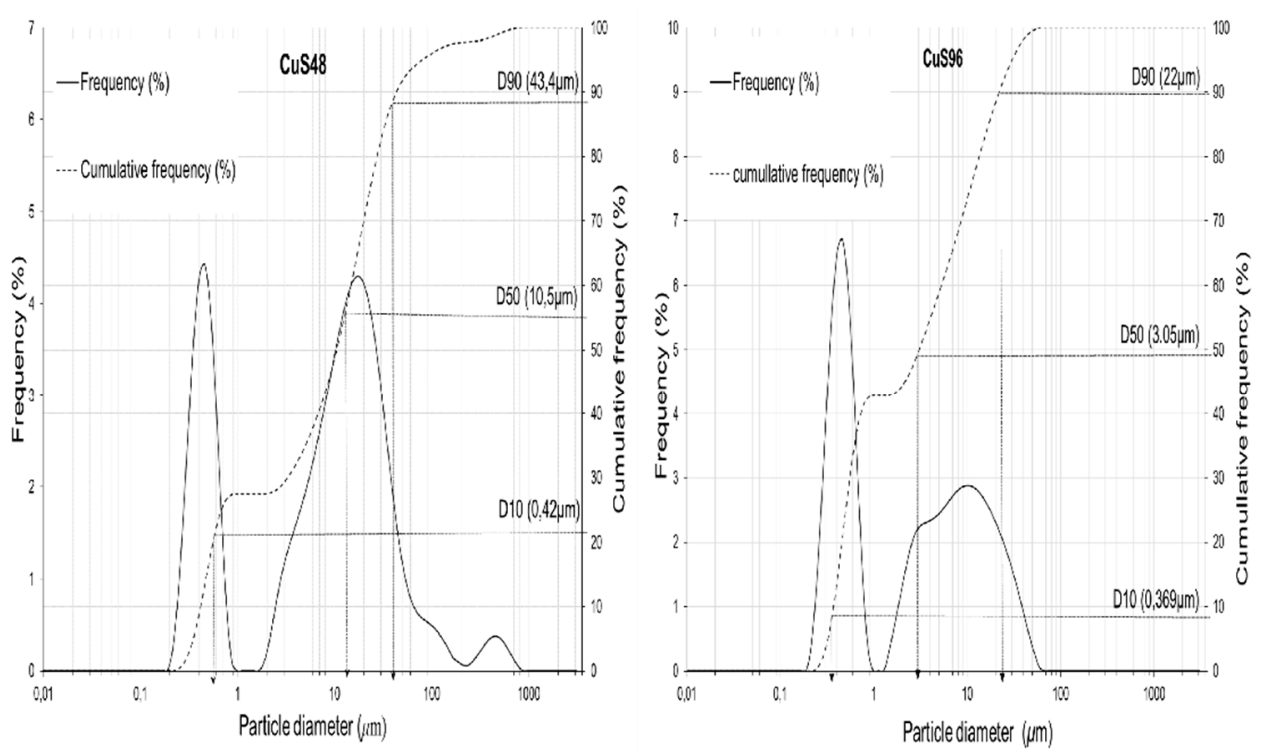

Figure 4. Polymodal, particles size (solid line), and cumulative (dotted line) distributions of CuS48 and CuS96 samples.

Figure 5 shows the SEM micrographs of samples CuS48 and CuS96 highlighting the hexagonal crystal habit predominant in covellite mineral structures [20]. SEM micrography also revealed typical covellite aggregates and placoid sheets. Covellite crystals were relatively smaller and more agglomerated in the CuS48 sample compared to sample CuS96, which showed well-formed uniform placoid sheets. Therefore, the time of crystallization is an important variable regarding shape-controlled biosulfidogenic covellite synthesis.

On average, placoid sheet's size varied between $0.2-0.6 \mu \mathrm{m}$, with the exception of bigger hexagonal crystal structures found in sample CuS96, reaching between 1.0-1.2 $\mu \mathrm{m}$ size. Crystal agglomeration during submicron and nanosized chemical CuS synthesis is a common phenomenon in the absence of dispersant or capping agent compounds [22]. The crystal structure of covellite obtained via the biosulfidogenic route was similar to the chemical route described in the literature [23], suggesting this method can be adopted to copper recovery from soluble copper containing solutions other than AMD. Placoid sheets visualized along the grain is typical of covellite morphology, since this mineral has perfect cleavage in the \{0001\} plane with flexible sheets [24]. According to Rask and co-workers [18] the $c$-axis of their obtained covellite crystals were preferentially aligned parallel to the longitudinal. SEM analysis confirmed the hypothesis that different forms of covellite crystal arrays may be obtained by varying the AMD time of exposure to biogenic $\mathrm{H}_{2} \mathrm{~S}$ produced by SRB consortia. 

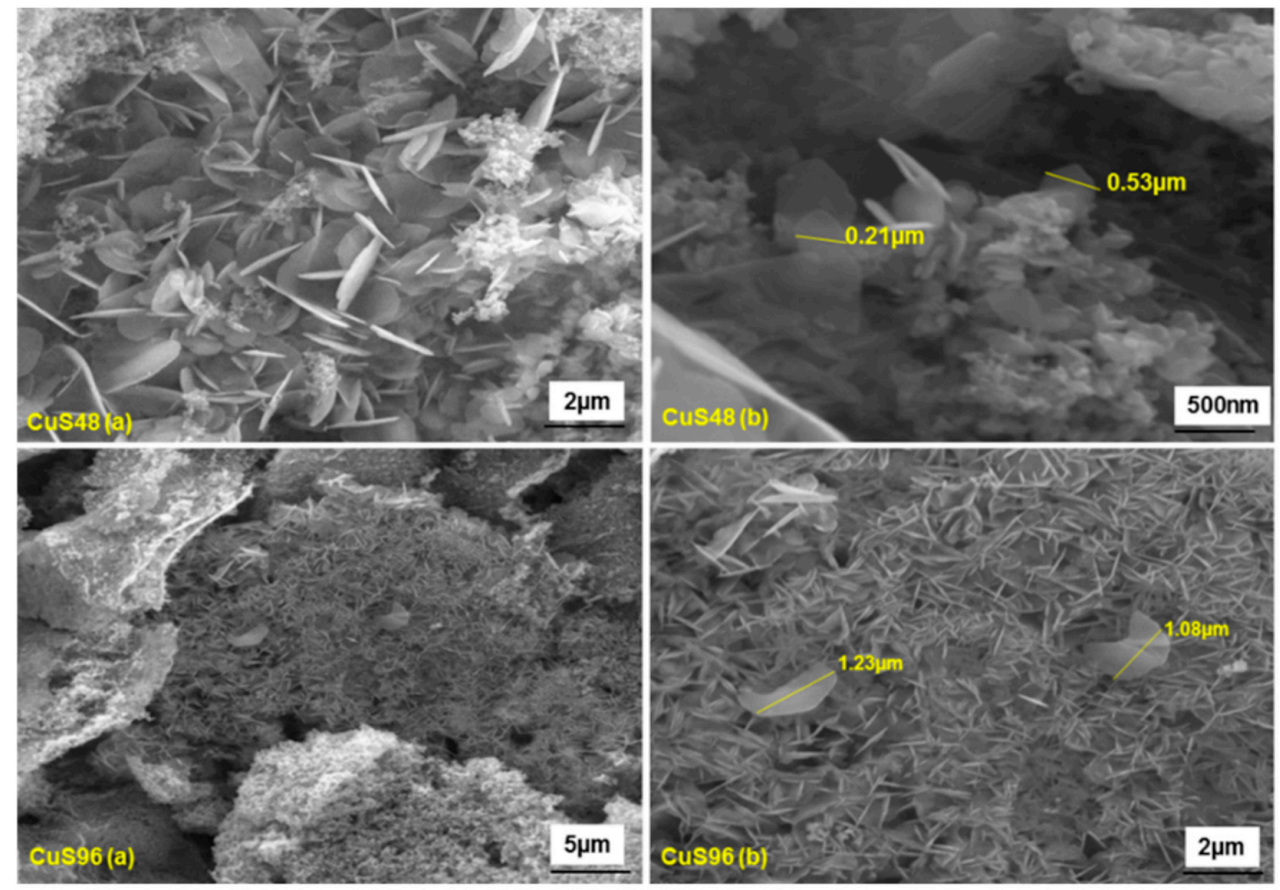

Figure 5. Scanning electrons microscopy (SEM) images of CuS48 and CuS96 samples with aggregate grains, placoid sheets, and hexagonal habit.

Pure covellite crystals are rare under natural conditions, being mostly associated to other copper minerals such as bornite [18]. AMD biosulfidogenic treatment can be a high-throughput source of pure covellite for industrial applications. Covellite exhibits semiconductor properties and can be used in photocatalytic reactions [25], as a semiconductor [22], in solar cells [26], as adsorbents [25], and in electronic devices. Recently, Colipai and colleagues [27] described the synthesis of copper nanoparticles from a copper sulfate solution $\left(2 \mathrm{mM} \mathrm{CuSO}_{4}\right)$ in the presence of a citrate buffer $(\mathrm{pH}$ 6.0) by biosulfidogenesis, opening a new frame for potential covellite applications in the development of nanostructures such as, nanotubes, nanoplatelets, and nanowires [28]. Copper nanoparticles have been chemically synthetized from $\mathrm{CuSO}_{4} \cdot 5 \mathrm{H}_{2} \mathrm{O}$ solution in the presence of ascorbic acid (surface agent), sodium borohydride (reducing agent), and sodium hydroxide ( $\mathrm{pH}$ adjust) [29]. New studies will be necessary for optimizing covellite nanoparticle synthesis conditions when using real AMD samples as substrates.

The biosulfidogenic method can either be applied to soluble metal precipitation from other polluting organic and/or inorganic effluents beyond AMD, or coupling the environmental remediation process to valuable product generation in accordance with circular economy principles [30]. Novel studies are necessary for upscaling covellite production to industrial-level demand.

The present work evaluated the isolated effect of $\mathrm{H}_{2} \mathrm{~S}$ time of exposure on covellite crystals' morphology obtained from a real AMD sample. Other variables, such as, temperature, $\mathrm{H}_{2} \mathrm{~S}$ inflow, and ultrasonic treatment, will be tested in future works to determine the edges of covellite synthesis and transformations required for specific applications.

\section{Conclusions}

The results confirm that the biosulfidogenic process is an efficient high-throughput method for obtaining pure and well-formed covellite crystals coupled to AMD treatment. The synthetized covellite crystals' size and structure were affected by changing the $\mathrm{Cu}: \mathrm{S}$ molar ratio in function of AMD sample exposure time to biogenic $\mathrm{H}_{2} \mathrm{~S}$. The longer exposure time ( $96 \mathrm{~h}$ ) favored covellite nucleation, resulting in well-developed crystals. Other parameters may be evaluated during biosulfidogenic covellite synthesis to develop new particle characteristics. 
Author Contributions: Conceptualization, I.P.N.C., G.C.d.O., and J.O.A.; methodology, I.P.N.C.; formal analysis, P.M.P.S., A.R.L., and J.A.P.B.; investigation, P.M.P.S. and A.L.V.d.C.; validation, I.P.N.C., G.C.d.O., and J.O.S.; writing-original draft preparation, P.M.P.S., A.R.L., and J.O.A.; project administration, G.C.d.O. and J.O.A.; funding acquisition, J.O.S.

Funding: This project was supported by the Industry Innovation Call (CNI-Brazil). Fellowships were granted by the National Council for Scientific and Technological Development (CNPq), and Fondo Nacional de Desarrollo Científico y Tecnológico (Fondecyt-Chile).

Conflicts of Interest: The authors declare no conflicts of interest.

\section{References}

1. Skousen, J.G.; Ziemkiewicz, P.F.; McDonald, L.M. Acid mine drainage formation, control and treatment: Approaches and strategies. Extr. Ind. Soc. 2018, 6, 214-249. [CrossRef]

2. Kefeni, K.K.; Msagati, T.A.M.; Mamba, B.B. Acid mine drainage: Prevention, treatment options, and resource recovery: A review. J. Clean. Prod. 2017, 151, 475-493. [CrossRef]

3. Nancucheo, I.; Bitencourt, J.A.P.; Sahoo, P.K.; Alves, J.O.; Siqueira, J.O.; Oliveira, G. Recent developments for remediating acidic mine waters using sulfidogenic bacteria. Biomed. Res. Int. 2017, 2017, 1-17. [CrossRef] [PubMed]

4. Świerczek, L.; Cieślik, B.M.; Konieczka, P. The potential of raw sewage sludge in construction industry-A review. J. Clean. Prod. 2018, 200, 342-356. [CrossRef]

5. Rückert, C. Sulfate reduction in microorganisms-Recent advances and biotechnological applications. Curr. Opin. Microbiol. 2016, 33, 140-146. [CrossRef] [PubMed]

6. da Costa, J.P.; Girão, A.V.; Lourenço, J.P.; Monteiro, O.C.; Trindade, T.; Costa, M.C. Green synthesis of covellite nanocrystals using biologically generated sulfide: Potential for bioremediation systems. J. Environ. Manag. 2013, 128, 226-232. [CrossRef] [PubMed]

7. Basheer, A.A. New generation nano-adsorbents for the removal emerging contaminants in water. J. Mol. Liquids 2018, 261, 583-593. [CrossRef]

8. Singh, A.; Manivannan, R.; Noyel, V.S. Simple one-pot sonochemical synthesis of copper sulphide nanoparticles for solar cell applications. Arab. J. Chem. 2015, 8, 1-9. [CrossRef]

9. Qu, X.; Alvarez, P.J.J.; Li, Q. Applications of nanotechnology in water and wastewater treatment. Water Res. 2013, 47, 3931-3946. [CrossRef] [PubMed]

10. da Coutinho, M.G.N. Geologia do craton Amazônico. In Província Miner do Tapajós: Geologia, Metalogenia e Mapa Previsional Para Ouro; CPRM: Rio de Janeiro, Brazil, 2008; Volume 428, pp. 15-31.

11. Grainger, C.J.; Groves, D.I.; Tallarico, F.H.B.; Fletcher, I.R. Metallogenesis of the Carajás mineral province, southern Amazon craton, Brazil: Varying styles of archean through Paleoproterozoic to Neoproterozoic baseand precious-metal mineralisation. Ore Geol. Rev. 2008, 33, 451-489. [CrossRef]

12. Pinheiro, W.F.; Filho, O.B.F.; Neves, C.A.R. Anuário Mineral Brasileiro, Departamento Nacional de Produção Mineral. DNPM. Available online: http:/ /www.anm.gov.br/dnpm/publicacoes/serie-estatisticase-economia-mineral/anuario-mineral/anuario-mineral-brasileiro (accessed on 5 November 2019).

13. Nancucheo, I.; Johnson, D.B. Selective removal of transition metals from acidic mine waters by novel consortia of acidophilic sulfidogenic bacteria. Microb. Biotechnol. 2012, 5, 34-44. [CrossRef] [PubMed]

14. Santos, A.L.; Johnson, D.B. The effects of temperature and $\mathrm{pH}$ on the kinetics of an acidophilic sulfidogenic bioreactor and indigenous microbial communities. Hydrometallurgy 2016, 168, 116-120. [CrossRef]

15. Shea, D.; Helz, G.R. Solubility product constants of covellite and a poorly crystalline copper sulfide precipitate at 298 K. Geochim. Cosmochim. Acta 1989, 53, 229-236. [CrossRef]

16. Ajibade, P.A.; Botha, N.L. Synthesis and structural studies of copper sulfide nanocrystals. Results Phys. 2016, 2016, 581-589. [CrossRef]

17. Yoshimura, M. Hydrothermal Processing of Materials: Past, Present and Future. J. Mat. Sci. 2017, 43, 2085-2103. [CrossRef]

18. Rask, H.; Frøkiær, M.; Warner, T.E. A morphological study of the sulfurisation of digenite to covellite using re fl ected polarised light microscopy. Solid State Sci. 2017, 70, 74-80. [CrossRef]

19. Lewis, A.E. Review of metal sulphide precipitation. Hydrometallurgy 2010, 104, 222-234. [CrossRef]

20. Freeda, A.M.; Madhav, R.N. Synthesis and characterization of nano-structured materials CuS (covellite) for their applications. Nanotechnol. Nanosci. 2010, 1, 976-7630. [CrossRef] 
21. Torrecillas, C.M.; Halbert, G.W.; Lamprou, D.A. A novel methodology to study polymodal particle size distributions produced during continuous wet granulation. Int. J. Pharm. 2017, 519, 230-239. [CrossRef]

22. Yadav, S.; Bajpai, P.K. Synthesis of copper sulfide nanoparticles: pH dependent phase stabilization. Nano-Struct. Nano-Objects 2017, 10, 151-158. [CrossRef]

23. Gramp, J.P.; Sasaki, K.; Bigham, J.M.; Karnachuk, O.V.; Tuovinen, O.H. Formation of covellite (CuS) under biological sulfate-reducing conditions. J. Geomicrobiol. 2006, 23, 613-619. [CrossRef]

24. Tailor, J. Existing Information on Covellite Copper Sulphide (CuS). Ph.D. Thesis, Sardar Patel University, Gujarat, India, 2014.

25. Ayodhya, D.; Veerabhadram, G. A review on recent advances in photodegradation of dyes using doped and heterojunction based semiconductor metal sulfide nanostructures for environmental protection. Mater. Today Energy 2018, 9, 83-113. [CrossRef]

26. Fang, J.; Zhang, P.; Chang, H.; Wang, X. Hydrothermal synthesis of nanostructured CuS for broadband efficient optical absorption and high-performance photo-thermal conversion. Sol. Energy Mater. Sol. Cells 2018, 185, 456-463. [CrossRef]

27. Colipai, C.; Southam, G.; Oyarzúm, P.; González, D.; Díaz, V.; Contreras, B.; Nancucheo, I. Synthesis of copper sulfide nanoparticles using biogenic $\mathrm{H}_{2} \mathrm{~S}$ produced by a low-pH sulfidogenic bioreactor. Minerals 2018, 8, 35. [CrossRef]

28. Tezuka, K.; Sheets, W.C.; Kurihara, R.; Shan, Y.J.; Imoto, H.; Marks, T.J. Synthesis of covellite (CuS) from the elements. Solid State Sci. 2007, 9, 95-99. [CrossRef]

29. Khalid, H.; Shamaila, S.; Zafar, N. Synthesis of copper nanoparticles by chemical reduction method. Sci. Int. 2015, 27, 3085-3088. [CrossRef]

30. Nascimento, D.N.O.; Lucheta, A.R.; Palmieri, M.C.; Carmo, A.L.V.; Silva, P.M.P.; Ferreira, R.V.P.; Junca, E.; Grillo, F.F.; Alves, J.O. Bioleaching for copper extraction of marginal ores from the Brazilian Amazon Region. Metals 2019, 9, 81. [CrossRef]

(C) 2019 by the authors. Licensee MDPI, Basel, Switzerland. This article is an open access article distributed under the terms and conditions of the Creative Commons Attribution (CC BY) license (http:/ / creativecommons.org/licenses/by/4.0/). 